\title{
Analisis Kemampuan Pemecahan Masalah Matematis Siswa dalam Pembelajaran Berbasis Lesson Study for Learning Community Berdasarkan Gaya Belajar Kolb
}

\author{
Dedi Ahmad Syaputra ${ }^{1}$, Mulyono², Hasratuddin ${ }^{3}$ \\ ${ }^{1,2,3}$ Prodi Pendidikan Matematika Pascasarjana, Universitas Negeri Medan \\ Universitas Negeri Medan, Jalan William IskandarPasar V, Medan, Indonesia \\ dediahmadsyaputra@mhs.unimed.ac.id
}

\begin{abstract}
This study aims to 1) analyze the level of problem-solving skills that are studied based on the learning style of the implementation of Lesson Study for Learning Community Learning in SMA Muhammadiyah 1 Medan students; 2) To find out the errors and difficulties experienced by students of SMA Muhammadiyah 1 Medan in solving mathematical problem-solving abilities that are learned from learning styles after Lesson Study for Learning Community. The type of research used in this research is descriptive-qualitative research. The subject of this study involved students of class XI MIA SMA Muhammadiyah 1 Medan who were given the Learning Community learning treatment in the even semester of the 2021/2022 Academic Year which accommodated 36 students. The regsults of the study show that 1) From the results of the classification of learning styles, there are more divergent learning styles than other learning styles. However, the divergent learning style is the learning style that gets the highest score in the problem-solving ability test, but the convergent learning style that gets the highest score in the mathematical problem-solving ability test; 2) Convergent, diverger, accommodator, and assimilator students are able to solve problems through the stage of understanding the problem by knowing what is known and developed in the problem and able to explain the problem in their own sentences.
\end{abstract}

Keywords: problem-solving ability, learning style, Lesson Study for Learning Community

\begin{abstract}
Abstrak
Penelitian ini bertujuan untuk 1) menganalisis tingkat kemampuan pemecahan masalah matematis siswa ditinjau berdasarkan gaya belajar setelah pelaksanaan Pembelajaran Lesson Study for Learning Community pada siswa SMA Muhammadiyah 1 Medan; 2) Untuk menganalisis kesalahan dan kesulitan yang dialami siswa SMA Muhammadiyah 1 Medan dalam menyelesaikan soal kemampuan pemecahan masalah matematis siswa ditinjau dari gaya belajar setelah pelaksanaan Pembelajaran Lesson Study for Learning Community. Jenis penelitian yang digunakan dalam penelitian ini adalah penelitian deskriptif-kualitatif. Subjek penelitian ini melibatkan siswa kelas XI MIA SMA Muhammadiyah 1 Medan yang diberi perlakuan pembelajaran Lesson Study for Learnig Community pada semester genap Tahun Ajaran 2021/2022 yang berjumlah 36 siswa. Hasil penelitian menunjukkan bahwa 1) Dari hasil klasifikasi gaya belajar, pada gaya belajar divergen lebih banyak dari pada gaya belajar yang lain. Namun gaya belajar divergen bukanlah gaya belajar yang mendapatkan nilai tertinggi dalam tes kemampuan pemecahan masalah, akan tetapi gaya belajar konvergen yang mendapatkan nilai tertinggi dalam hal tes kemampuan pemecahan masalah matematis.; 2) Siswa converger, diverger, accommodator, dan assimilator mampu memecahkan masalah dengan melalui tahap memahami masalah dengan mengetahui apa yang diketahui dan ditanyakan pada masalah serta mampu menjelaskan masalah dengan kalimat sendiri.
\end{abstract}

Kata kunci: kemampuan pemecahan masalah, gaya belajar, Lesson Study for Learning Community

Copyright (c) 2022 Dedi Ahmad Syaputra, Mulyono, Hasratuddin

$\square$ Corresponding author: Dedi Ahmad Syaputra

Email Address: dediahmadsyaputra@mhs.unimed.ac.id (Jalan William IskandarPasar V, Medan, Indonesia)

Received 23 December 2021, Accepted 05 February 2022, Published 07 February 2022

\section{PENDAHULUAN}

Menurut Hasratuddin (Hasratuddin, 2013) bahwa "matematika adalah ilmu tentang logika mengenai bentuk, susunan, besaran, konsep-konsep berhubungan lainnya dengan jumlah yang banyak yang terbagi kedalam tiga bidang, yaitu aljabar, analisis, dan geometri”. Matematika juga bukanlah 
suatu alat bantu untuk berhitung dan berpikir saja, tetapi bisa juga sebagai alat bantu untuk menentukan pola, berkomunikasi, memecahkan masalah, dan juga menarik kesimpulan.

Akan Tetapi sebagian besar siswa masih beranggapan matematika itu sulit. Kesulitan yang dialami siswa dalam belajar matematika kerap kali mengakibatkan rendahnya hasil belajar matematika siswa. Beberapa siswa mungkin kompeten dalam memecahkan masalah, tetapi mengalami kesulitan belajar rumus matematika. Siswa biasanya mendapatkan nilai rendah dalam kinerja mereka dalam matematika karena kurangnya konsep pemahaman tentang dasar manipulasi atau keterampilan matematika (Kartimi et al., 2013)

Tentunya masalah yang dihadapi setiap individu berbeda-beda, masalah yang dihadapi seseorang dalam belajar matematika biasa direpresentasikan dengan soal yang dianggap sulit oleh peserta didik. Proses dalam menyelesaikan soal tersebut dibutuhkan suatu kemampuan matematis yang mendukung salah satunya kemampuan pemecahan masalah matematis. Oleh karena itu, kemampuan pemecahan masalah matematis memiliki peran penting yaitu agar peserta didik tersebut dapat menerapkan kemampuan pemecahan masalah yang dimiliki dalam menghadapai suatu permasalahan di kehidupan nyata. Ismawati (Rostika \& Junita, 2017) menjelaskan bahwa "kemampuan pemecahan masalah amatlah penting bukan saja bagi mereka yang kemudian hari akan mendalami matematika, melainkan juga bagi mereka yang akan menerapkannya dalam bidang studi lain maupun kehidupan sehari-hari."

Meskipun pemecahan masalah merupakan aspek yang penting, tetapi kemampuan pemecahan masalah matematika siswa saat ini masih rendah. Rendahnya kemampuan pemecahan masalah matematika siswa tersebut dapat dilihat dari hasil tes Programme for International Student Assessment (PISA) terhadap kompetensi matematika. Dimana keikutsertaan Indonesia dalam tes PISA pada tahun 2003, 2006, 2009, 2012, 2015, dan 2018 memperoleh hasil yang kurang memuaskan. Pada tes PISA tahun 2003, dalam bidang matematika, Indonesia berada di peringkat 38 dari 41 negara dengan rataan skor 360 dari rataan skor internasional 496. Pada tahun 2006 rataan skor siswa naik menjadi 391 dengan peringkat 50 dari 57 negara. Pada tahun 2009 Indonesia menempati peringkat 61 dari 65 negara dengan rataan turun menjadi 371. Menurut (Citra \& Hasanah, 2015) Pada tahun 2012 Indonesia berada di peringkat kedua terbawah, hanya unggul dari negara Peru dengan skor 375 yaitu berada pada peringkat 64 dari 65 negara yang mengikuti tes. Berdasarkan hasil tes PISA tahun 2015 (OECD, 2016), pada tahun 2015 menyatakan Indonesia berada pada peringkat 63 dari 70 negara dengan rataan skor 386 dari rataan skor internasional 490. Berdasarkan hasil tes PISA menurut (OECD, 2019) , pada tahun 2018 menyatakan Indonesia berada pada peringkat 63 dari 80 negara dengan rataan skor 379 .

Pentingnya kemampuan pemecahan masalah juga diungkapkan oleh Branca, sebagaimana dikutip oleh (Effendi, 2012). bahwa kemampuan pemecahan masalah adalah jantungnya matematika. Kemampuan pemecahan masalah siswa memiliki keterkaitan dengan tahap menyelesaikan masalah matematika. Menurut Polya (Polya, 1973), tahap pemecahan masalah matematika meliputi: (1) 
memahami masalah, (2) membuat rencana penyelesaian, (3) melaksanakan rencana, dan (4) melihat kembali. Hal ini dimaksudkan supaya siswa lebih terampil dalam menyelesaikan masalah matematika, yaitu terampil dalam menjalankan prosedur-prosedur dalam menyelesaikan masalah secara cepat dan cermat seperti yang diungkapkan oleh Hudojo (Hudojo, 2005). Tahap pemecahan masalah menurut Polya juga digunakan secara luas di kurikulum matematika di dunia dan merupakan tahap pemecahan masalah yang jelas.

Berdasarkan hasil observasi pada bulan Desember 2020 di SMA Muhammadiyah 1 Medan, rata-rata nilai Ujian Semester (US) Ganjil tahun pelajaran 2020/2021 kelas XI mata pelajaran matematika adalah 68,5 lebih rendah dari KKM yaitu 75. Hal ini menunjukkan bahwa kemampuan pemecahan masalah matematika siswa kelas XI di SMA Muhammadiyah 1 Medan. Siswa mempunyai kebiasaan melihat cara penyelesaian pada contoh soal sejenis yang pernah dikerjakan. Ini menyebabkan siswa tidak dapat memecahkan masalah sendiri dengan baik dan melihat pekerjaan orang lain apabila mendapatkan soal yang tidak sederhana.

Berdasarkan hasil observasi diatas maka kemampuan pemecahan masalah matematis perlu mendapatkan perhatian karena merupakan kemampuan yang diperlukan dalam belajar. Seperti yang dinyatakan oleh National Council of Teachers of Mathematics (NCTM) (Surya \& Rahayu, 2021) bahwa "dalam pembelajaran matematika siswa harus memiliki kemampuan matematis, yaitu kemampuan komunikasi, pemecahan masalah, penalaran, koneksi, dan representasi matematika untuk mencapai tujuan pembelajaran matematika". Kemampuan pemecahan masalah matematika dapat mendorong siswa dalam belajar bermakna dan belajar kebersamaan, selain itu dapat membantu siswa dalam menghadapi permasalahan keseharian secara umum. Dengan demikian pemecahan masalah matematika memiliki peran yang cukup besar bagi siswa. Akan tetapi kegiatan pemecahan masalah dalam proses pembelajaran belum menjadi kegiatan utama sehingga masih banyak siswa yang merasa kesulitan dan merasa menderita menghadapi pemecahan masalah.

Salah satu cara untuk meningkatkan kemampuan pemecahan masalah adalah dengan menggunakan pembelajaran berbasis Lesson Study for Learning Community (LSLC). LSLC berbeda dengan konsep lesson study. Lesson study for learning community, lebih menekankan pengkajian pada bagaimana peserta didik belajar dan berkolaborasi, dibandingkan dengan pengkajian tentang bagaimana guru mengajar dan penguasaan materi. Seperti yang dikemukakan oleh Purwandi et al (Purwandi et al., 2020) pada penelitiannya bahwa LSLC dapat meningkatkan kemampuan pemecahan masalah peserta didik dan melatih komunikasi saat kegiatan berdikusi. Hal tersebut juga dikemukakan oleh Rachamawati et al. (Rachamawati et al., 2021) bahwa proses pembelajaran dengan pembelajaran STEM berbasis LSLC membuahkan hasil yang baik untuk meningkatkan kemampuan pemecahan masalah dan kemandirian peserta didik.

Menurut Peker (Peker, 2009) "berbagai penelitian telah menunjukkan bahwa banyak siswa memiliki kesulitan dalam belajar matematika serta lemah dalam prestasi di bidang matematika seperti kemampuan pemecahan masalah." Hal tersebut dapat diakibatkan oleh beberapa faktor dan variabel 
yang mempengaruhi seperti gaya belajar, kecemasan matematika, kurangnya rasa percaya diri, kepercayaan guru, lingkungan, kurangnya perhatian orang tua, serta jenis kelamin.

Gaya belajar siswa menurut Kolb sebagaimana dikutip oleh Ramadan, et al., (Ramadan et al., 2011) didasarkan pada 4 tahapan belajar. Kebanyakan orang melewati tahap-tahap ini dalam urutan concrete experiences, reflective observation, abstract conceptualization, dan active experimentation. Pada survei gaya belajar menurut Kolb menggunakan angket gaya belajar menurut Kolb pada siswa kelas XI SMA Muhammadiyah 1 Medan, ditemukan bahwa dari 32 siswa kelas X MIA 2 terdapat 16 siswa yang memiliki gaya belajar converger, 6 siswa memiliki gaya belajar diverger, 8 siswa memiliki gaya belajar accommodator, dan 2 siswa memiliki gaya belajar assimilator. Ini berarti dalam satu kelas ditemukan tipe gaya belajar yang berbeda-beda. Identifikasi gaya belajar siswa oleh guru merupakan hal yang sangat penting. Hal ini dikarenakan bahwa siswa yang mengetahui tipe gaya belajar mereka akan menyesuaikan diri dengan pembelajaran di kelas agar sukses dalam belajar. Sementara itu, identifikasi gaya belajar belajar menurut Bhat (Bhat, 2014) bahwa "dapat membantu siswa untuk menjadi problem solver yang efektif." Lebih lanjut lagi, menurut Ozgen, et al. (Ozgen, C., Nijkamp, P., Poot, 2011) bahwa "gaya belajar sendiri merupakan salah satu faktor yang mempengaruhi bagaimana siswa belajar matematika."

Dalam pendekatan penemuan terbimbing, guru harus memberikan kesempatan siswanya untuk menjadi seorang problem solver, seorang saintis, dan ahli matematika. Kemudian dapat membangun kepercayaan diri, minat dan ketertarikan siswa kepada matematika, sehingga dengan menerapkan pendekatan penemuan terbimbing dalam pembelajaran diharapkan dapat membuat siswa semakin menyukai matematika.

\section{METODE}

Jenis penelitian yang digunakan dalam penelitian ini adalah penelitian deskriptif-kualitatif. Ciri-ciri penelitian kualitatif menurut Moleong (Moleong, 2010) adalah: (1) mempunyai latar alamiah, (2) peneliti sebagai instrumen utama, (3) menggunakan metode kualitatif, (4) analisis data secara induktif, (5) teori dari dasar, (6) bersifat deskriptif, (7) lebih mementingkan proses daripada hasil, (8) adanya batas yang ditentukan oleh fokus, (9) adanya kriteria khusus untuk keabsahan data, (10) desain yang bersifat sementara, dan (11) hasil penelitian dirundingkan dan disepakati bersama."

Subjek penelitian ini melibatkan siswa kelas XI MIA SMA Muhammadiyah 1 Medan yang diberi perlakuan pembelajaran Lesson Study for Learnig Community pada semester genap Tahun Ajaran 2021/2022 yang berjumlah 36 siswa.

Mekanisme yang digunakan dalam penelitian ini meliputi tiga tahap yaitu

1. Tahap penyusunan perangkat pembelajaran dan instrument penelitian

2. Tahap validasi perangkat pembelajaran

3. Tahap pelaksanaan penelitian dan analisis data. 
Setiap tahapan dirancang sedemikian sehingga diperoleh data yang valid dan reliable sesuai tujuan penelitian. Dalam penelitian ini juga dikembangkan secara sederhan instrument penelitian untuk mempertajam serta melengkapi data hasil penelitian. Instrumen tersebut antara lain: Instrumen angket gaya belajar berdasarkan teori kolb, tes kemampuan pemecahan masalah, dan pedoman wawancara.

\section{Instrumen Angket Gaya Belajar}

Pada penelitian ini akan gaya belajar siswa akan diukur dengan instrumen berupa angket KLSI (Kolb Learning Style Inventory) yang diambil dari website Miami University yaitu pada http://www.units.miamioh.edu/dalam bahasa inggris. Selanjutnya diterjemahkan ke dalam bahasa Indonesia dengan pertimbangan dosen pembimbing.

Gaya belajar Experiential Learning Kolb dibentuk dua deskripsi bipolar. Deskripsi bipolar pertama pada posisivertikal berupa pengalaman konkret (feeling) konseptualisasi abstrak (thinking) yang berpotongan dengan deskripsibipolar kedua yang berposisi horisontal, yaitu melakukan (doing), mengamati(watching). Seperti yang digambarkan pada bagan berikut:

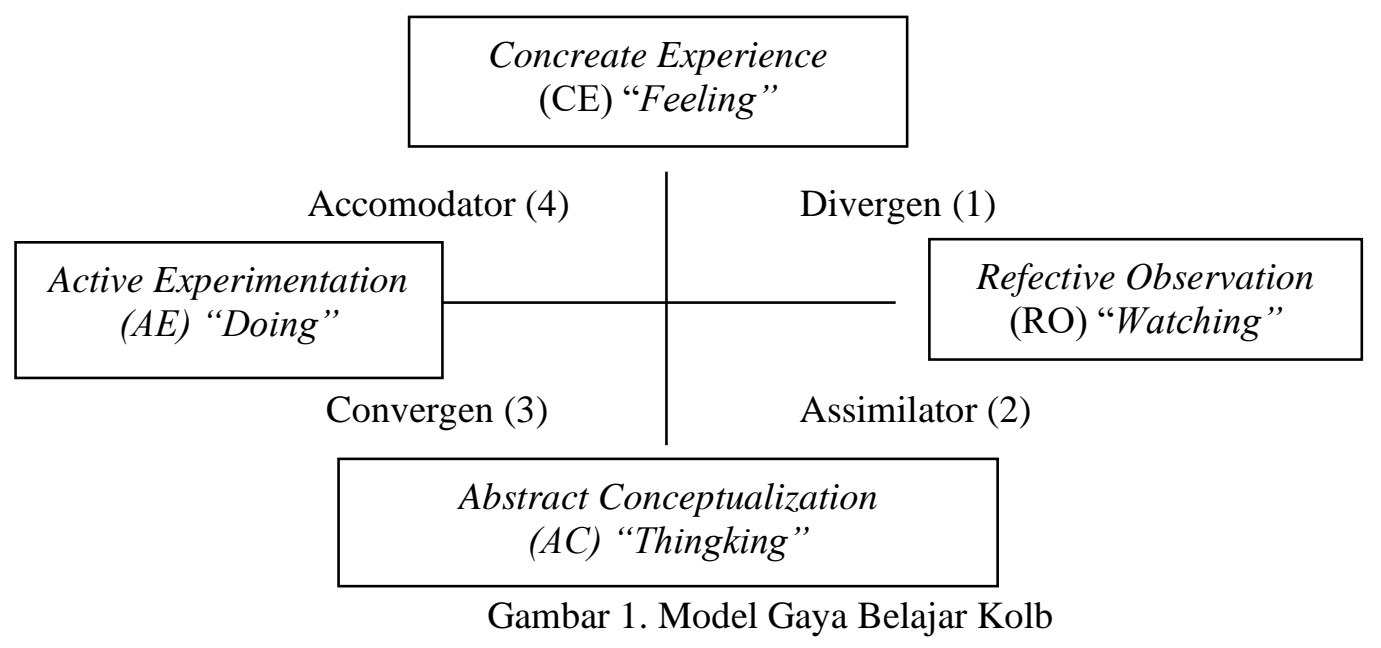

\section{Instrumen Tes Kemampuan Pemecahan Masalah}

Data kemampuan pemecahan masalah matematis siswa diperoleh melalui pemberian tes tertulis setelah seluruh rencana pelaksanaan pembelajaran matematika yakni dengan menerapkan pembelajaran lesson study for learning community. Instrumen tes ini digunakan untuk mengukur kemampuan pemecahan masalah matematis siswa dalam menguasai materi barisan dan deret.

\section{Pedoman Wawancara}

Penyusunan instrumen pedoman wawancara dilakukan dengan mengacu kepada tahap pemecahan masalah menurut Polya. Pertanyaan wawancara bertujuan untuk mengetahui deskripsi kemampuan pemecahan masalah siswa. Hasil wawancara tidak terlampir dalam transkrip, namun hanya dalam bentuk recorder.

Analisis data yang digunakan dalam penelitian ini, yaitu analisa data kualitatif. Analisis kualitatif digunakan untuk menganalisis data kemampuan pemecahan masalah matematis siswa, data 
angket gaya belajar, dan data angket respon siswa melalui pembelajaran lesson study for learning community.

Gaya belajar seseorang diketahui dengan cara mencari skor kombinasi, yaitu dengan menghitung skor AE dikurangi dengan skor $\mathrm{CE}$ serta skor AC dikurangi skor CE. Menurut Kolb sebagaimana dikutip oleh Cavas (Cavas, 2010) gaya belajar yang bersesuai dengan seseorang dapat ditunjukkan dengan memplotkan skor kombinasi seperti pada Gambar 1.

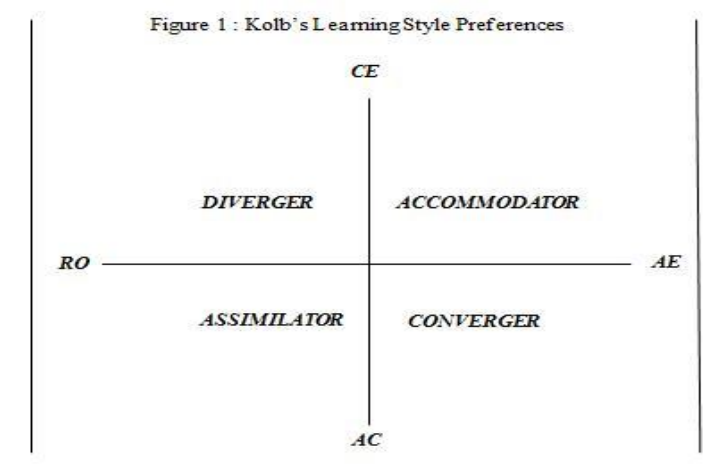

Gambar 1. Ploting gaya belajar menurut Kolb

Adapun dalam pendekatan kualitatif yang digunakan dalam penelitian ini mengikuti konsep yang diberikan Miles dan Huberman. Sebagaimana yang disampaikan, Sugiyono (Sugiyono, 2016) bahwa "terdiri dari tiga alur kegiatan yang terjadi interaktif dan berlangsung secara terus menerus sampai tuntas". Aktivitas dalam analisis data yaitu: Reduksi Data (Data Reduction), Penyajian Data (Data Display), dan Penarikan Kesimpulan (Conclusion)". Untuk lebih jelasnya proses tersebut dapat dilihat dalam Gambar 2. berikut ini:

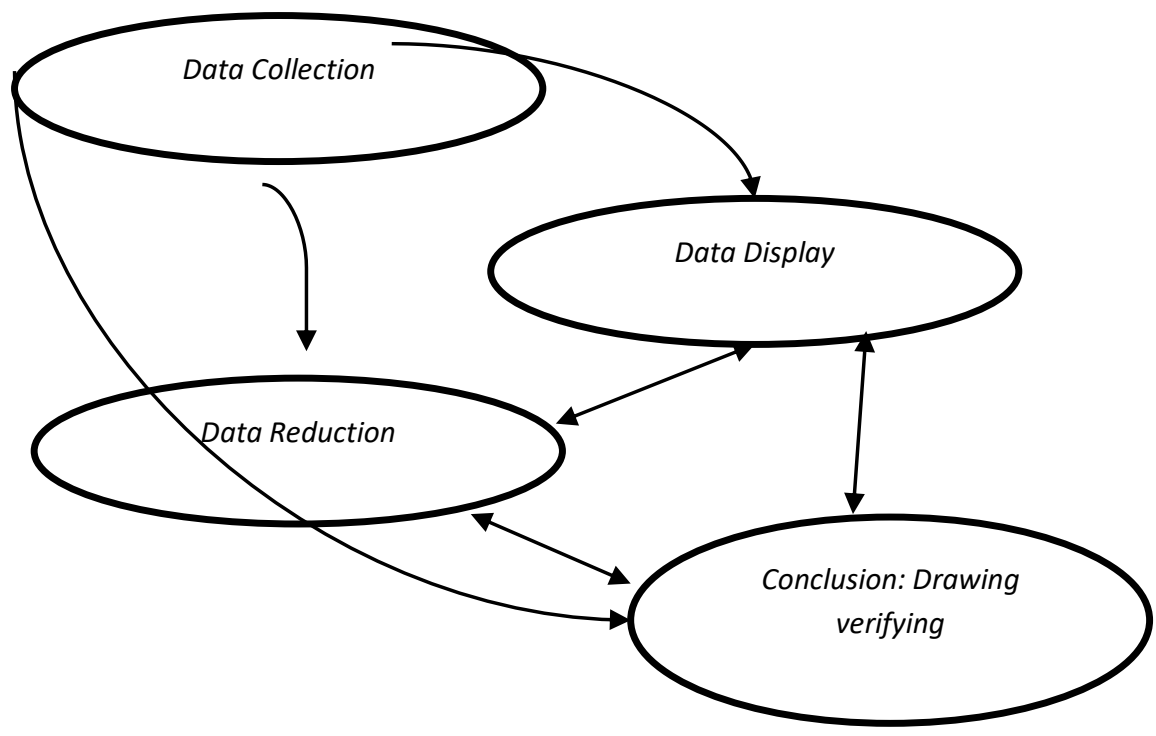

Gambar 2. Komponen Dalam Analisis Data (Interactive Model) Sumber: (Sugiyono, 2016) 


\section{HASIL DAN DISKUSI}

\section{Hasil Angket Gaya Belajar}

Berdasarkan hasil pengisian angket gaya belajar yang telah dilakukan oleh 36 siswa kelas XI Mia SMA Muhammadiyah 1 Medan maka diperoleh hasil gaya belajar yang ditunjukkan pada Tabel 1. di bawah ini.

Tabel 1. Hasil Angket Gaya Belajar Siswa

\begin{tabular}{|l|l|l|}
\hline Gaya Belajar & Jumlah Siswa & Presentase \\
\hline Akomodator & 7 Orang & $19,4 \%$ \\
\hline Diverger & 14 Orang & $38,8 \%$ \\
\hline Asimilator & 10 Orang & $27,7 \%$ \\
\hline Konverger & 5 Orang & $13,8 \%$ \\
\hline
\end{tabular}

Berdasarkan Tabel 1. diperoleh bahwa siswa yang menempati masing-masing gaya belajar Kolb. Siswa yang diklasifikasikan ke dalam gaya belajar Akomodator berjumlah 7 orang siswa $(19,4 \%)$. Siswa yang diklasifikasikan dalam gaya belajar Diverger berjumlah 14 orang $(38,8 \%)$. Siswa yang diklasifikasikan ke dalam gaya belajar Asimilator berjumlah 10 orang (27,7\%). Siswa yang diklasifikasikan ke dalam gaya belajar Konverger berjumlah 5 orang (13.8\%).

\section{Hasil Tes Kemampuan Pemecahan Masalah Dalam Matematika}

Adapun tingkat kemampuan kemampuan pemecahan masalah matematis siswa dapat dilihat pada Tabel 2. berikut ini.

Tabel 2. Tingkat Kemampuan Kemampuan Pemecahan Masalah Matematis Siswa

\begin{tabular}{|c|c|c|c|}
\hline Interval Nilai & Jumlah Siswa & Presentase & Kriteria Penilaian \\
\hline $0 \leq \mathrm{S}<50$ & 20 Orang & $55,55 \%$ & Rendah \\
\hline $50 \leq \mathrm{S}<80$ & 13 Orang & $36,11 \%$ & Sedang \\
\hline $80 \leq \mathrm{S} \leq 100$ & 3 Orang & $8,3 \%$ & Tinggi \\
\hline
\end{tabular}

Keterangan:

$\mathrm{S}=$ Skor Kemampuan Pemecahan Masalah Matematis Siswa

Berdasarkan Tabel 2. diperoleh bahwa tingkat kemampuan pemecahan masalah matematis siswa dengan kategori penilaian rendah berjumlah 20 orang $(55.55 \%)$, dengan kategori penilaian sedang berjumlah 13 orang $(36,11 \%)$, dan kategori penilaian tinggi berjumlah 3 orang $(8,3 \%)$. Berdasarkan Gambar 4.2. dapat disimpulkan bahwa tingkat kemampuan pemecahan masalah matematis siswa setelah pelaksanaan pembelajaran Lesson Study for Learning Community paling banyak pada kategori penilaian rendah.

Analisis Kemampuan Pemecahan Masalah Matematis Siswa Melalui Model Pembelajaran Lesson Study for Learning Community Ditinjau dari Gaya Belajar Siswa untuk Masalah 1

Tabel 3. Gaya Belajar Converger

\begin{tabular}{|l|c|l|}
\hline \multicolumn{1}{|c|}{ Indikator } & Ket & \multicolumn{1}{c|}{ Penjelasan dan Uraian } \\
\hline $\begin{array}{l}\text { Mengetahui apa yang diketahui dan } \\
\text { ditanyakan pada masalah }\end{array}$ & $\mathrm{M}$ & $\begin{array}{l}\text { Indikator ini muncul pada lembar jawaban milik C1. C1 } \\
\text { secara langsung menuliskan apa yang diketahui dari } \\
\text { masalah dan apa yang ditanya pada soal }\end{array}$ \\
\hline
\end{tabular}




\begin{tabular}{|l|c|l|}
\hline $\begin{array}{l}\text { Membuat rumus atau rencana untuk } \\
\text { memecahkan masalah tersebut }\end{array}$ & $\mathrm{M}$ & $\begin{array}{l}\text { Eksperimen dan simulasi muncul pada jawaban dari C1. } \\
\text { C1 membuat rencana penyelesaian dengan memilih rumus } \\
\text { yang tepat untuk penyelesaian masalah. }\end{array}$ \\
\hline $\begin{array}{l}\text { Memasukkan apa yang diketahui } \\
\text { dalam soal kedalam rumus yang } \\
\text { telah direncanakan }\end{array}$ & $\mathrm{M}$ & $\begin{array}{l}\text { Pada masalah 1, C1 mampu Memasukkan apa yang } \\
\text { diketahui dalam soal kedalam rumus yang telah } \\
\text { direncanakan, kemudian menghitung hasilnya }\end{array}$ \\
\hline $\begin{array}{l}\text { Mensubsitusikan hasil yang di dapat } \\
\text { ke soal yang diketahui }\end{array}$ & $\mathrm{M}$ & $\begin{array}{l}\text { C1 mampu memasukan hasil yang di dapat ke soal yang } \\
\text { diketahui }\end{array}$ \\
\hline
\end{tabular}

Tabel 4. Gaya Belajar Diverger

\begin{tabular}{|l|c|l|}
\hline \multicolumn{1}{|c|}{ Indikator } & Ket & \multicolumn{1}{c|}{ Penjelasan dan Uraian } \\
\hline $\begin{array}{l}\text { Mengetahui apa yang diketahui } \\
\text { dan ditanyakan pada masalah }\end{array}$ & $\mathrm{M}$ & $\begin{array}{l}\text { Indikator ini muncul pada lembar jawaban milik D1. } \\
\text { D1secara langsung menuliskan apa yang diketahui dari } \\
\text { masalah dan apa yang ditanya pada soal }\end{array}$ \\
\hline $\begin{array}{l}\text { Membuat rumus atau rencana } \\
\text { untuk memecahkan masalah } \\
\text { tersebut }\end{array}$ & $\mathrm{M}$ & $\begin{array}{l}\text { Eksperimen dan simulasi muncul pada jawaban dari D1. } \\
\text { Dilihat dari pekerjaan yang dilakukan oleh D1. D1 } \\
\text { membuat rencana penyelesaian dengan memilih rumus } \\
\text { yang tepat untuk penyelesaian masalah. }\end{array}$ \\
\hline $\begin{array}{l}\text { Memasukkan apa yang } \\
\text { diketahui dalam soal kedalam } \\
\text { rumus yang telah direncanakan }\end{array}$ & $\mathrm{M}$ & $\begin{array}{l}\text { Pada masalah 1, D1 mampu Memasukkan apa yang } \\
\text { diketahui dalam soal kedalam rumus yang telah } \\
\text { direncanakan, kemudian menghitung hasilnya }\end{array}$ \\
\hline $\begin{array}{l}\text { Mensubsitusikan hasil yang di } \\
\text { dapat ke soal yang diketahui }\end{array}$ & $\mathrm{M}$ & $\begin{array}{l}\text { D1 mampu memasukan hasil yang di dapat ke soal yang } \\
\text { diketahui }\end{array}$ \\
\hline
\end{tabular}

Tabel 5. Gaya Belajar Accommodator

\begin{tabular}{|l|c|l|l|}
\hline \multicolumn{1}{|c|}{ Indikator } & Ket & \multicolumn{1}{c|}{ Penjelasan dan Uraian } \\
\hline $\begin{array}{l}\text { Mengetahui apa yang diketahui } \\
\text { dan ditanyakan pada masalah }\end{array}$ & $\mathrm{M}$ & $\begin{array}{l}\text { Indikator ini muncul pada lembar jawaban milik Ac1. } \\
\text { Ac1 secara langsung menuliskan apa yang diketahui dari } \\
\text { masalah }\end{array}$ \\
\hline $\begin{array}{l}\text { Membuat rencana yang akan } \\
\text { dilakukan untuk menyelesaikan } \\
\text { masalah yang ada }\end{array}$ & $\mathrm{M}$ & $\begin{array}{l}\text { Eksperimen dan simulasi muncul pada jawaban dari } \\
\text { Ac1. Dilihat dari pekerjaan yang dilakukan oleh Ac1. } \\
\text { Ac1 membuat rencana penyelesaian dengan memilih } \\
\text { rumus yang tepat untuk penyelesaian masalah. }\end{array}$ \\
\hline $\begin{array}{l}\text { Memasukkan apa yang diketahui } \\
\text { dalam soal kedalam rumus yang } \\
\text { telah direncanakan }\end{array}$ & $\mathrm{M}$ & $\begin{array}{l}\text { Pada masalah 1, Ac1 mampu Memasukkan apa yang } \\
\text { diketahui dalam soal kedalam rumus yang telah } \\
\text { direncanakan, kemudian menghitung hasilnya }\end{array}$ \\
\hline $\begin{array}{l}\text { Mensubsitusikan hasil yang di } \\
\text { dapat ke soal yang diketahui }\end{array}$ & $\mathrm{M}$ & $\begin{array}{l}\text { Ac1 mampu memasukan hasil yang di dapat ke soal } \\
\text { yang diketahui }\end{array}$ \\
\hline
\end{tabular}

Tabel 6. Gaya Belajar Assimilator

\begin{tabular}{|l|c|l|}
\hline \multicolumn{1}{|c|}{ Indikator } & Ket & \multicolumn{1}{c|}{ Penjelasan dan Uraian } \\
\hline $\begin{array}{l}\text { Mengetahui apa yang diketahui } \\
\text { dan ditanyakan pada masalah }\end{array}$ & M & $\begin{array}{l}\text { Indikator ini muncul pada lembar jawaban milik As1. } \\
\text { As1 secara langsung menuliskan apa yang diketahui dari } \\
\text { masalah }\end{array}$ \\
\hline $\begin{array}{l}\text { Membuat rencana yang akan } \\
\text { dilakukan untuk menyelesaikan } \\
\text { masalah yang ada }\end{array}$ & M & $\begin{array}{l}\text { Eksperimen dan simulasi muncul pada jawaban dari As1. } \\
\text { Dilihat dari pekerjaan yang dilakukan oleh As1. As1 } \\
\text { membuat rencana penyelesaian dengan memilih rumus } \\
\text { yang tepat untuk penyelesaian masalah. }\end{array}$ \\
\hline Memasukkan apa yang diketahui & $\mathrm{M}$ & \begin{tabular}{l} 
Pada masalah 1, As1 mampu Memasukkan apa yang \\
\hline
\end{tabular} \\
\hline
\end{tabular}




\begin{tabular}{|l|c|l|}
\hline $\begin{array}{l}\text { dalam soal kedalam rumus yang } \\
\text { telah direncanakan }\end{array}$ & & $\begin{array}{l}\text { diketahui dalam soal kedalam rumus yang telah } \\
\text { direncanakan, kemudian menghitung hasilnya }\end{array}$ \\
\hline $\begin{array}{l}\text { Mensubsitusikan hasil yang di } \\
\text { dapat ke soal yang diketahui }\end{array}$ & M & $\begin{array}{l}\text { As1 mampu memasukan hasil yang di dapat ke soal yang } \\
\text { diketahui }\end{array}$ \\
\hline
\end{tabular}

\section{Diskusi}

\section{Klasifikasi Gaya Belajar Siswa}

Berdasarkan hasil penelitian diperoleh bahwa dari 36 siswa kelas XI MIA, Siswa yang diklasifikasikan ke dalam gaya belajar Akomodator berjumlah 7 orang siswa (19,4\%). Siswa yang diklasifikasikan dalam gaya belajar Diverger berjumlah 14 orang $(38,8 \%)$. Siswa yang diklasifikasikan ke dalam gaya belajar Asimilator berjumlah 10 orang (27,7\%). Siswa yang diklasifikasikan ke dalam gaya belajar Konverger berjumlah 5 orang (13.8\%). Dari hasil klasifikasi gaya belajar memang gaya belajar diverger lebih banyak dari pada gaya belajar yang lain. Namun gaya belajar diverger bukanlah gaya belajar yang mendapatkan nilai tertinggi dalam tes kemampuan pemecahan masalah, akan tetapi gaya belajar konverger yang mendapatkan nilai tertinggi dalam hal tes kemampuan pemecahan masalah matematis.

Hasil penelitian ini sejalan dengan hasil penelitian Azrai, dkk (Azrai et al., 2017) yang menyatakan bahwa siswa dengan gaya belajar diverger juga memiliki rata-rata nilai hasil belajar afektif yang paling rendah dan bebeda signifikan dengan gaya belajar accommodator dan converger. Siswa dengan gaya belajar diverger lebih unggul dalam hasil belajar psikomotorik, dibandingkan kognitif dan afektif. Hal tersebut dapat dilihat dari banyaknya jumlah siswa diverger yang memiliki nilai hasil belajar psikomotorik yang berkriteria baik dan sangat baik. Siswa dengan gaya belajar diverger memiliki nilai rata-rata hasil belajar psikomotorik tertinggi ketiga, namun tidak berbeda signifikan dengan ketiga gaya belajar lainnya. Gaya belajar diverger unggul dalam melihat situasi kongkret dari banyak sudut pandang berbeda.

Hasil penelitian ini juga sama dengan hasil penelitian (Peker, 2009) yang menemukan bahwa keberadaan gaya belajar yang persentasenya nilai nya dalam kemampuan pemecahan masalah paling tinggi di antara gaya belajar yang lain adalah gaya belajar converger. Hal yang serupa juga ditemukan pada penelitian Cavas (Cavas, 2010) bahwa gaya belajar converger dan assimilator lebih tinggi nilainya dalam kemampuan pemecahan masalah diantara gaya belajar lainnya. Pada penelitian ini, gaya converger memiliki persentase keberadaan yang paling dominan dibandingkan dengan gaya belajar yang lain. Kolb \& Kolb (Kolb \& Kolb, 2005) menyatakan bahwa siswa yang memiliki gaya belajar converger lebih menyukai tugas dan masalah yang sifatnya teknis daripada masalah sosial dan masalah antar pribadi. Kekuatan terbesar dari siswa converger terletak pada aplikasi praktis dari ideide. Matematika pada dasarnya adalah sebuah pelajaran yang dapat diaplikasikan dalam kehidupan sehari-hari dimana siswa converger sangat tertantang untuk melihatnya melalui pelajaran Matematika.

Kolb \& Kolb (Kolb \& Kolb, 2005) juga menyatakan bahwa siswa yang memiliki gaya belajar assimilator kurang terfokus pada orang-orang dan lebih tertarik pada ide-ide dan konsep abstrak. 
Siswa assimilator menyukai pelajaran matematika karena matematika merupakan kumpulan konsepkonsep yang abstrak. Hal ini berbeda dengan siswa yang memiliki gaya belajar diverger. Dan siswa yang memiliki gaya belajar diverger memiliki ketertarikan pada budaya.

\section{Deskripsi Kemampuan Pemecahan Masalah Matematis Siswa Ditinjau dari Gaya Belajar}

\section{Deskripsi Tingkat Kemampuan Pemecahan Masalah Matematis Siswa dengan Gaya Belajar Akomodator}

Berdasarkan hasil pengelompokkan gaya belajar siswa maka siswa kelasXI Mia SMA Muhammadiyah 1 Medan dengan gaya belajar akomodasi terdiri dari 7 orang. Berdasarkan hasil pengelompokkan gaya belajar siswa diperoleh bahwa tingkat kemampuan pemecahan masalah matematis siswa dengan kategori penilaian rendah berjumlah 4 orang $(57.14 \%)$, dengan kategori penilaian sedang berjumlah 3 orang $(42,86 \%)$, dan tidak ada siswa dengan gaya belajar akomodasi dengan kategori penilaian tinggi. Berdasarkan data di atas, dari 7 orang siswa gaya belajar akomodasi hanyaberada pada kategori penilaian rendah dan sedang.

\section{Deskripsi Tingkat Kemampuan Pemecahan Masalah Matematis Siswa dengan Gaya Belajar Diverger}

Berdasarkan hasil pengelompokkan gaya belajar siswa maka siswa kelas XI Mia SMA Muhammadiyah 1 Medan dengan gaya belajar divergen terdiri dari 14orang. Berdasarkan hasil pengelompokkan gaya belajar siswa diperoleh bahwa tingkat kemampuan pemecahan masalah matematis siswa dengan kategori penilaian rendah berjumlah 7 orang (50\%), dengan kategori penilaian sedang berjumlah 4 orang $(28,57 \%)$, dan dengan kategori penilaian tinggi berjumlah 3 orang $(21,42 \%)$. Berdasarkan data di atas, siswa dengan gaya belajar divergen sudah ada yang berada pada kategori tinggi.

\section{Deskripsi Tingkat Kemampuan Pemecahan Masalah Matematis Siswa dengan Gaya Belajar Asimilator}

Berdasarkan hasil pengelompokkan gaya belajar siswa maka siswa kelas XI Mia SMA Muhammadiyah 1 Medan dengan gaya belajar asimilasi terdiri dari 10 orang. Berdasarkan hasil pengelompokkan gaya belajar siswa diperoleh bahwa tingkat kemampuan pemecahan masalah matematis siswa dengan kategori penilaian rendah berjumlah 8 orang (80\%), dengan kategori penilaian sedang berjumlah 2 orang (20\%), dan tidak ada siswa dengan gaya belajar asimilasi dengan kategori penilaian tinggi. Berdasarkan data di atas, dari 10 orang siswa gaya belajar asimilasi hanya berada pada kategori penilaian rendah dan sedang.

\section{Deskripsi Tingkat Kemampuan Pemecahan Masalah Matematis Siswa dengan Gaya Belajar Konverger}

Berdasarkan hasil pengelompokkan gaya belajar siswa maka siswa kelas XI Mia SMA Muhammadiyah 1 Medan dengan gaya belajar konvergern terdiri dari 5 orang. Berdasarkan hasil pengelompokkan gaya belajar siswa diperoleh bahwa tingkat kemampuan pemecahan masalah matematis siswa dengan kategori penilaian Tinggi berjumlah 2 orang (40\%), dengan kategori 
penilaian sedang berjumlah 3 orang (60\%), dan tidak ada siswa dengan gaya belajar konvergen dengan kategori penilaian tinggi. Berdasarkan data di atas, dari 5 orang siswa gaya belajar konvergen hanya berada pada kategori peneliaian rendah dan sedang.

Dari paparan data diatas dapat dilihat bahwa Gaya belajar dapat mempengaruhi kemampuan pemecahan masalah matematis siswa. Hal itu sejalan dengan penelitian yag dilakukan oleh Wicaksono, dkk (Wicaksono et al., 2021) yang menunjukkan bahwa mahasiswa dengan gaya belajar diverging, subjek laki-laki berada pada kategori kurang dan subjek perempuan berada pada kategori cukup dalam pemecahan masalah. Kemampuan mahasiswa dengan gaya belajar assimilating, baik subjek laki-laki maupun perempuan berada pada kategori cukup dalam pemecahan masalah. Kemampuan mahasiswa dengan gaya belajar converging, baik subjek laki-laki maupun perempuan berada pada kategori cukup dalam pemecahan masalah. Kemampuan mahasiswa dengan gaya belajar accommodating, baik subjek laki-laki maupun perempuan berada pada kategori cukup dalam pemecahan masalah.

\section{Deskripsi Kesalahan Siswa dalam Menyelesaikan Soal Kemamampuan Pemecahan Masalah Matematis Siswa}

Setelah mendeskripsikan kesalahan siswa dari masing-masing gaya belajar, selanjutnya akan dideskripsikan kesalahan bersama berdasarkan masing-masing indikator untuk setiap gaya belajar. Berdasarkan deskripsi kesalahan siswadalam menyelesaikansoal kemampuan pemecahan masalah matematis siswa ditinjau dari gaya belajarakan dirangkum dominan kesalahan siswa berdasarkan masing-masing indikator seperti pada Tabel 7. berikut.

Tabel. 7. Kesalahan Siswa dalam Menyelesaikan Soal Kemampuan Pemecahan Masalah Matematis Siswa

\begin{tabular}{|l|l|l|l|l|}
\hline \multirow{2}{*}{$\begin{array}{l}\text { Gaya } \\
\text { Belajar }\end{array}$} & \multicolumn{4}{|l|}{ Indikator Kemampuan Pemecahan Masalah Matematis Siswa } \\
\cline { 2 - 5 } & I & II & III & IV \\
\hline Akomodasi & Soal 4,6 & Soal 2, 3 & Soal 2, 3, 4, 5, 6 & Soal 1, 2, 3, 4, 5, 6 \\
\hline Divergen & Soal 5, 6 & Soal 4, 5, 6 & Soal 4, 5, 6 & Soal 2, 3, 4, 5, 6 \\
\hline Asimilasi & Soal 4, 5, 6 & Soal 2, 3, 4, 5,6 & Soal 2, 3, 4, 5, 6 & Soal 2, 3, 4, 5,6 \\
\hline Konvergen & Soal 3, 5,6 & Soal 2, 3, 5,6 & Soal 4, 5,6 & Soal 4, 5, 6 \\
\hline
\end{tabular}

Berdasarkan Tabel 7. adapun kesalahan siswa dalam menyelesaikan soalkemampuan kreatif dalam matematika adalah sebagai berikut:

1. Pada indikator memahami masalah siswa dominan salah pada soal nomor 6 . Soal nomor 6 memiliki daya pembeda pada kategori baik dan dengantingkat kesukaran soal paling tinggi dibandingkan dengan soal lainnya. Soal ini menuntut siswa untuk dapat menyelesaikan nilai dari suatu fungsidengan berbagai cara.

2. Pada indikator membuat rencana penyelesaian siswa dominan salah pada soal nomor $4,5,6$. soal nomor 4, 5, dan 6 ini memiliki daya pembeda pada kategori baik sekali dan dengan tingkat kesukaran pada kedua soal ini hampir sama. Soal 2 dan 3 ini menuntut siswa untuk dapat membuat rumus ataupun konsep dari penyelesaian masalah tersebut. 
3. Pada indikator melaksanakan rencana penyelesaian siswa dominan salah pada soal nomor 4,5 dan 6. Soal nomor 4, 5 dan 6 memiliki memiliki daya pembeda pada kategori baik dan dengan kesukaran soal paling tinggi dibandingkan dengan soal lainnya, Pada indikator memeriksa kembali siswa dominan salah/tidak memeriksa kembali pada soal nomor 4, 5 dan 6. Soal nomor 4, 5 dan 6 memiliki memiliki daya pembeda pada kategori baik dan dengan kesukaran soal paling tinggi dibandingkan dengan soal lainnya.

\section{KESIMPULAN}

Siswa yang diklasifikasikan ke dalam gaya belajar Akomodator berjumlah 7 orang siswa $(19,4 \%)$. Siswa yang diklasifikasikan dalam gaya belajar Divergen berjumlah 14 orang $(38,8 \%)$. Siswa yang diklasifikasikan ke dalam gaya belajar Asimilasi berjumlah 10 orang $(27,7 \%)$. Siswa yang diklasifikasikan ke dalam gaya belajar Konvergen berjumlah 5 orang (13.8\%). Dari hasil klasifikasi gaya belajar memang gaya belajar divergen lebih banyak dari pada gaya belajar yang lain. Namun gaya belajar divergen bukanlah gaya belajar yang mendapatkan nilai tertinggi dalam tes kemampuan pemecahan masalah, akan tetapi gaya belajar konvergen yang mendapatkan nilai tertinggi dalam hal tes kemampuan pemecahan masalah matematis.

Siswa converger, diverger, accommodator, dan assimilator mampu memecahkan masalah dengan melalui tahap memahami masalah dengan mengetahui apa yang diketahui dan ditanyakan pada masalah serta mampu menjelaskan masalah dengan kalimat sendiri. Namun ada beberapa soal dengan tingkat kesukaran yang tinggi siswa masih ada yang belum mampu memecahkan masalah pada indikator pemecahan masalah memeriksa kembali.

\section{UCAPAN TERIMA KASIH}

Terima kasih saya ucapkan kepada dosen pembimbing Bapak Dr. Mulyono, M.Si dan Bapak Prof. Dr. Hasratuddin, M.Pd. Terima kasih juga saya ucapkan untuk semua pihak yang membantu dalam menyelesaikan penelitian ini.

\section{REFERENSI}

Azrai, E. P., Ernawati, E., \& Sulistianingrum, G. (2017). Pengaruh Gaya Belajar David Kolb (Diverger, Assimilator, Converger, Accommodator) Terhadap Hasil Belajar Siswa Pada Materi Pencemaran Lingkungan. Biosfer: Jurnal Pendidikan Biologi, 10(1), 9-16. https://doi.org/10.21009/biosferjpb.10-1.2

Bhat, M. A. (2014). International Journal Advances in Social Science and Humanities Available online at: www.ijassh.com The Effect of Learning Styles on Problem Solving Ability among High School Students. International Journal Advances in Social Science and Humanities, 2(7), $40-43$.

Cavas, B. (2010). A Study on Pre-service S Styles in Turkey. Science Education International, 21(1), 
$47-61$.

Citra, I., \& Hasanah, A. (2015). Studi Cross-Sectional Tingkat Kemampuan Literasi Matematis Siswa Sekolah Menengah Pertama di Bandung Berdasarkan Pengujian Soal PISA. Edisi, 2(3), 10-25. www.juliwi.com

Effendi, L. A. (2012). Pembelajaran Matematika dengan Metode Penemuan Terbimbing Untuk Meningkatkan Kemampuan Representasi dan Pemecahan Masalah Matematis Siswa SMP. Jurnal Penelitian Pendidikan, 13(2), 1-10. http://jurnal.upi.edu/file/Leo_Adhar.pdf

Hasratuddin. (2013). Membangun Karakter Melalui Pembelajaran Matematika. Jurnal Pendidikan Matematika PARADIKMA, 6(2), 130-141. http://digilib.unimed.ac.id/id/eprint/960

Hudojo, H. (2005). Pengembangan Kurikulum dan Pembelajaran Matematika. Universitas Negeri Malang.

Kartimi, Gloria, R. Y., \& Ayani. (2013). Penerapan Pendekatan Keterampilan Proses dalam Pengajaran Biologi untuk Mengetahui Hasil Belajar Siswa Pada Pokok Bahasan Ekosistem Kelas VII di SMPN 1 Talun. Jurnal Scientiae Educatia, 2(1), 73-85. http://www.syekhnurjati.ac.id/jurnal/index.php/sceducatia/article/view/524

Kolb, A. Y., \& Kolb, D. A. (2005). Learning styles and learning spaces: Enhancing experiential learning in higher education. Academy of Management Learning and Education, 4(2), 193-212. https://doi.org/10.5465/AMLE.2005.17268566

Moleong. (2010). Metode Penelitian Kualitatif. Remaja Rosdakarya.

OECD. (2016). Results: Excellence and Equity in Education: Vol. I. https://doi.org/10.1787/9789264266490-5-en

OECD. (2019). Results (Volume I): What Students Know and Can Do: Vol. I. https://doi.org/10.1787/5f07c754-en

Ozgen, C., Nijkamp, P., Poot, J. (2011). Immigration and Innovation in European Regions. IZA Institute for the Study of Labour.

Peker, M. (2009). Pre-service teachers' teaching anxiety about mathematics and their learning styles. Eurasia Journal of Mathematics, Science and Technology Education, 5(4), 335-345. https://doi.org/10.12973/ejmste/75284

Polya, G. (1973). How to Solve it. Princeton University Press.

Purwandi, D., Susanto, \& Hobri. (2020). Development of remedial mathematics learning based on lesson study for learning community against students' problem solving analysis capabilities. Journal of Physics: Conference Series, 1563(1). https://doi.org/10.1088/17426596/1563/1/012038

Rachamawati, A. D., Kusumah, Y. S., \& Dadang, J. (2021). Kemampuan pemecahan masalah dan kemandirian belajar menggunakan pendekatan stem berbasis lesson study for learning community. 10(4), 2636-2645.

Ramadan, Ipek, \& Nazan. (2011). an Investigation of the Learning Styles of. 1(3), 1-6. 
Rostika, D., \& Junita, H. (2017). Peningkatan Kemampuan Pemecahan Masalah Siswa Sd Dalam Pembelajaran Matematika Dengan Model Diskursus Multy Representation (Dmr). EduHumaniora | Jurnal Pendidikan Dasar Kampus Cibiru, 9(1), 35. https://doi.org/10.17509/eh.v9i1.6176

Sugiyono. (2016). Metode Penelitian Kuantitatif, Kualitatif, Dan R\&D. alfabeta.

Surya, E., \& Rahayu, R. (2021). PEMECAHANMASALAH MATEMATIS SISWA SMP AR-RAHMAN PERCUT MELALUI PEMBELAJARAN KOOPERATIF TIPE STUDENT TEAMS ACHIEVEMENT DIVISION ( STAD ). 7, 24-34.

Wicaksono, A. B., Chasanah, A. N., \& Sucoko, H. (2021). KEMAMPUAN PEMECAHAN MASALAH GEOMETRI BERBASIS BUDAYADITINJAU DARI GENDER DAN GAYA BELAJAR. AKSIOMA : Jurnal Program Studi Pendidikan Matematika, 10(1), 240-251. 